\title{
Guillain-Barré syndrome: celebrating a century
}

\section{Síndrome de Guillain-Barré: celebração de um século}

Marcos R. G. de Freitas ${ }^{1}$, Cecilia M. Vidal', Marco Orsini²

\begin{abstract}
A hundred years ago, Guillain, Barré and Strohl described a syndrome with a predominant motor acute or subacute polyneuritis, albumin-cytologic dissociation in the cerebrospinal fluid, and a benign course. Before them, many other authors, such as Landry, Duménil, Osler, and Grainger Stewart had described similar cases although they had not performed lumbar punctures. In this work, we outline certain features of the beginning of this famous syndrome.
\end{abstract}

Keywords: Guillain-Barre syndrome; neuritis

\section{RESUMO}

Há 100 anos três médicos franceses, Guillain, Barré e Strohl descreveram um tipo de polineuropatia aguda ou subaguda de predomínio motor com dissociação albumino-citológica no líquido cefalorraquiano e de evolução benigna. Antes destes, outros autores, como Landry, Duménil, Chomel, Osler e Grainger Stewart, estudaram casos similares, porém não realizaram punção lombar. Neste trabalho procuramos sintetizar alguns fatos importantes no início da descrição desta síndrome.

Palavras-chave: síndrome de Guillain-Barré, neurite.

In 2016, a century had passed since the famous description of a syndrome of an acute, ascendant and symmetrical paralysis involving the peripheral nerves with an albumin-cytologic dissociation in the cerebrospinal fluid and a good recovery, by three French neurologists: Guillain, Barré and Strohl. This syndrome, well known as "Guillain-Barré syndrome", is the most common cause of acute flaccid paralysis in the world. In June 2016, a symposium in Glasgow celebrated a century of Guillain-Barré syndrome, patronized by the Peripheral Nerve Society ${ }^{1}$.

\section{Guillain-Barré history}

In 1916, Georges Charles Guillain, Jean Alexandre Barré and André Strohl (Figure 1) described in Bulletins et Mémoires de la Société Médicale des Hôpitaux de Paris², a new syndrome in two young French soldiers characterized by motor disturbance, abolition of the tendon reflex, paresthesia with mild disturbance of sensation, slight changes in electric reaction of nerves and muscles and hyperalbuminosis of the cerebrospinal fluid with absence of cytological reaction (albumin-cytologic dissociation). The cases were presented at the Medical Society of the Hospitals in Paris on October $16^{\text {th }} 1916$, under the title "Sur un syndrome de radiculonévrite avec hyperalbuminose du liquide céphalorachidien sans reaction cellulaire. Remarques sur le caractères cliniques et graphiques des réflexes tendineux" (Figure 2). They thought that this syndrome was due to involvement of the spinal roots and nerves, probably infectious or toxic in nature. The treatment consisted of rest, massage and injections of strychnine. Both patients recovered after a few months.

Guillain became professor of Neurology at the Salpêtrière Hospital in Paris. Barré was professor of Neurology at Strasbourg. They became friends at the "Centre Neurologique" of the $6^{\text {th }}$ army near Amiens during the first world war, which is where they saw these cases ${ }^{3}$. Strohl was forgotten, probably because of his young age and his participation was limited to electrophysiology.

\section{Early description}

In 1850, Jean Baptiste Octave Landry de Théizillat (1826-1865) (Figure 3) wrote "Note sur la paralysie ascendante aigue" where he reported on 10 patients, five of whom he had personally examined ${ }^{4}$. He described three types of presentation: ascending paralysis without sensory signs or symptoms; ascending paralysis with ascending anesthesia, and a progressive disorder characterized by paralysis and slight sensory loss. His first patient, a 43-year-old

${ }^{1}$ Universidade Federal Fluminense, Hospital Universitário Antonio Pedro, Serviço de Neurologia; Rio de Janeiro RJ, Brasil;

${ }^{2}$ Universidade Severino Sombra, Programa de Mestrado em Ciências Aplicada em Saúde, USS, Vassouras RJ, Brasil.

Correspondence: Marcos R. G. de Freitas; Rua Gastão Ruch, 16 / apt 1402; 24220-100 Niterói RJ, Brasil; E-mail:mgdefreitas@outlook.com

Conflict of Interest: There is no conflict of interest to declare.

Received 25 February 2017; Received in final form 10 May 2017; Accepted 16 May 2017. 

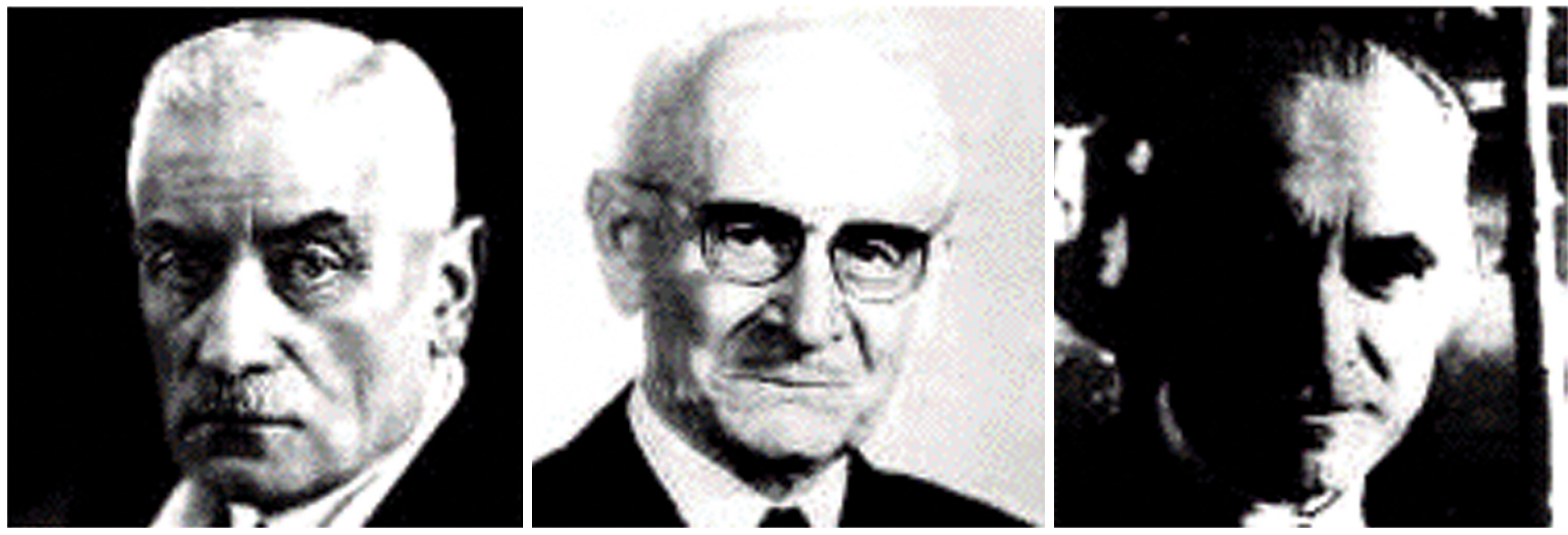

Figure 1. Georges Charles Guillain (1876-1971), Jean Alexandre Barré (1880-1967) and André Strohl (1887-1977).

Bulletin de la Sociéze Médicale des Hópitanx de Ponis, 1916; 40: 1462-1470

Y SCI UN SYNDRONE DE RADICLLO-SÉVRTE AVEC UTPERALBUYINOSE DE LLUUIDE

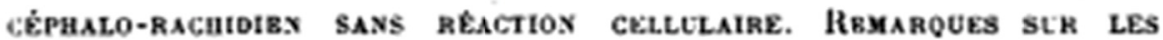
CARACTÈRES CLIXIQUES ET GRAPIQUES DES RÝ.FLEXES TENDISEUX.

par MM. Gzorges Guillain, J.-A. Barkí et A. Stroul.

Nuus attirons l'attention, dans la présente note, sur un syndrome clinique que nous arons observé chez deux malades, syndrome caractérisé par des troubles moteurs, l'abolition des réflexes tendineux avec conservation des rédexes cutanés, des paresthésies avec troubles légers de la sensibilité objective, des douleurs a la pression des masses musculaires, des modifications peu accentuées des réactions électriques des nerfs et des muscles, de l'hyperalbuminose très notable du liquide céphalo-rachidien avec absence de réaction cytologique (dissociation albumino-cytologique). Ce syndrome nous a paru dépendre d'une atteinte concomitante des racines rachidiennes, des nerfs et des muscles, vraisemblablement de nature infectieuse ou toxique. Il doit étre différencié des radiculites simples, des polynévrites pures et des polymyosites. Des recherches expérimentales par la méthode graphique sur la vitesse des réflexes et leur temps perdu, sur les modalités, la contractilité musculaire, montrent la réalité de la participation, dans ce sysdrome, de tout l'appareil moteur neuro-musculaire périphérique. Nous insistons particulièrement aussi sur l'hyperalbuminose du liquide céphalo-rachidien sans réaction cytologique, fait qui, à notre connaissance, n'a pas été mentionné dans des cas semblables.

Figure 2. Original article by Gullain-Barré-Strohl.

man, after a premonitory fever, complained of "weakness, tingling his fingers and toes". Touch sensation was lost in the fingers and feet but was little impaired in the upper two thirds of the lower limbs. The paralysis ascended, with sensory loss. By the third week, his limbs were paralyzed, he developed difficulty in breathing and swallowing, with fever and coughing. Touch was lost in the feet and in the finger tips, but without pain and temperature loss. He died in the third week. Necropsy included histological examination only of the cord and soleus muscle. The main difference between that report and the syndrome described by Guillain, Barré and Strohl was that Landry did not perform a lumbar puncture, as this was introduced by Quincke only in 1891.

Landry was a gentle and modest man. At the age of 40, while attending the victims of a cholera epidemic in Paris, 


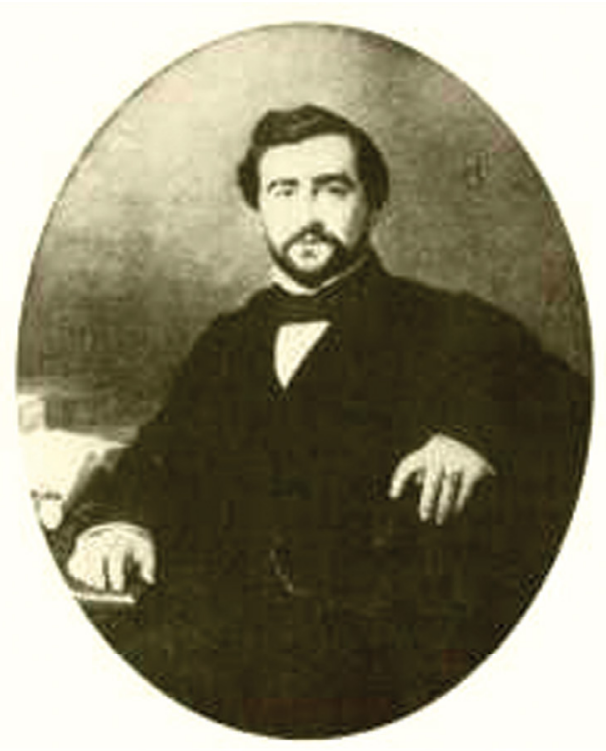

I.

\section{TRABAOX ORGGLALX.}

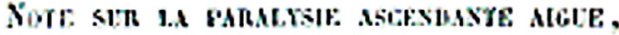 par le doctetur 0 . Isxistix.}

I.objet de celle note est do signaler un élat morjiule assez rane et ginerahement inconou, mais giai mírils de ligurer parmi les affections les plus renateguables des otalies pathologinues.

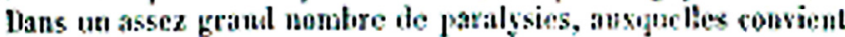

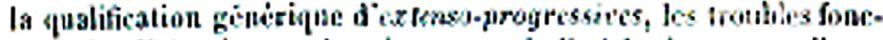
lionnels, d'abord restreints a une partie limitec itu corps, sirsa. dient graduellement plus ou moins loin de leur point ite depart. Celte propagation s'eftectue tantio de proche en proclio, ot al'apres

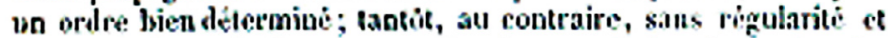
comze au hasard. On peut appeler les paralysics de ce dernier groupe : exdensomprogressives irrecigulices, ef a cellos ilu prennicr, bjen plas importaales a connaitre, donner le nori diexlenso-progressiets uscentantes, on, plus simplement, de pitralysies ascendankes on centripites. Lans ces abjections, en etfet, les symplònts

Figure 3. Jean Baptiste Octave Landry de Théizillat (1826-1865).

Landry contracted the illness and died a few days later. Haymaker called this syndrome the "Landry-Guillain-Barré syndrome" and included the name of Landry as one of the fathers of Neurology ${ }^{6}$. Landry's description probably included all types of acute or subacute ascending paralysis, such as some cases of poliomyelitis or ascending myelitis. In 1864, Louis Stanislas Duménil, in Rouen, described one case of an acute and symmetrical ascending paralysis. He thought it was due to nerve atrophy. Three years later he described three other cases ${ }^{1}$.

Sir William Osler (1849-1919) in "The Principles and Practice of Medicine" (Figure 4) wrote about an ascending paralysis he referred to as an acute infectious polyneuritis ${ }^{3}$. Guillain and Barré did not accept that description, as Osler's patient had fever in the beginning of the disease and had no lumbar puncture ${ }^{7}$.

In Paris in 1828, Auguste François Chomel (1788-1858) described a patient with disturbed sensations in their hands and feet, ascendant weakness with acute evolution, becoming paralytic within a few days ${ }^{1}$. In 1881, Thomas Stewart (1837-1900), in Edinburgh, reported on three cases of that same illness, calling attention to the loss of tendon reflexes ${ }^{1}$.

\section{Soon after 1916}

Draganesco and Claudian were the first to use the term "Guillain-Barré syndrome" in $1927^{1}$.

In 1936, Guillain published ten nonfatal cases and established the main conditions of this syndrome: 1) albumin-cytologic dissociation in the cerebral spinal fluid; 2) onset with paralysis and paresthesia or pain, with or without premonitory symptoms; 3 ) flaccid paralysis of the lower limbs and later in the upper limbs; 4) occasional fibrillatory twitching and slight atrophy of the distal muscles; 5) abolition

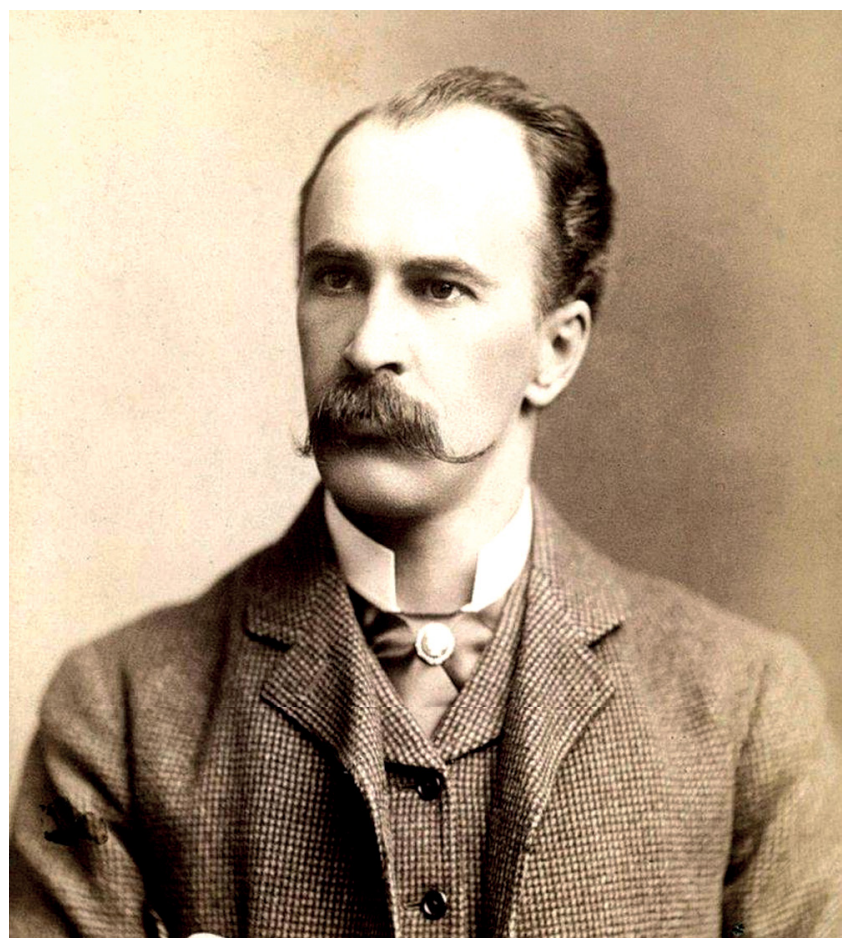

Figure 4. Willian Osler (1849-1919).

of tendon reflexes; 6) presence of subjective sensory disturbance; 7) objective minor or transitory changes in sensibility; 8) transitory paralysis of the cranial nerves; 9) transitory sphincter disturbance ${ }^{8}$.

In the same year, Alajouanine published a similar case in which death had occurred9.

Guillain and Barré ${ }^{7}$ refused to accept the cases described without albumin-cytologic dissociation in the cerebral spinal fluid, and in the cases with fatal outcome, Landry and Alajouanine were the objects of attack by Guillain ${ }^{1,3}$. Firstly 
because they did not mention the albumin-cytologic dissociation in the cerebral spinal fluid, and secondly, because the patients died from the disease. Two years later, Guillain accepted that this syndrome could be fatal ${ }^{3}$.

The first case in Brazil was described by Antonio Rodrigues de Mello (Figure 5) in a soldier who, without prodromal symptoms, presented with a subacute ascending paralysis, slight sensory disturbances in the limbs with paralysis of the trigeminal and facial nerves. The cerebral spinal fluid showed an albumin-cytologic dissociation. He was treated with intravenous and intrathecal vitamin B and recovered in a few weeks. Mello believed that the disease was due to lack of vitamins or due to a neurotrophic virus ${ }^{10}$.

\section{Conclusion}

The history of Guillain-Barré syndrome continues today. Many advances have been made in the epidemiology, clinical variants, atypical cases, electrophysiology findings, pathogenesis, preceding infections and vaccinations, nerve images, treatment and rehabilitation. These are another story.

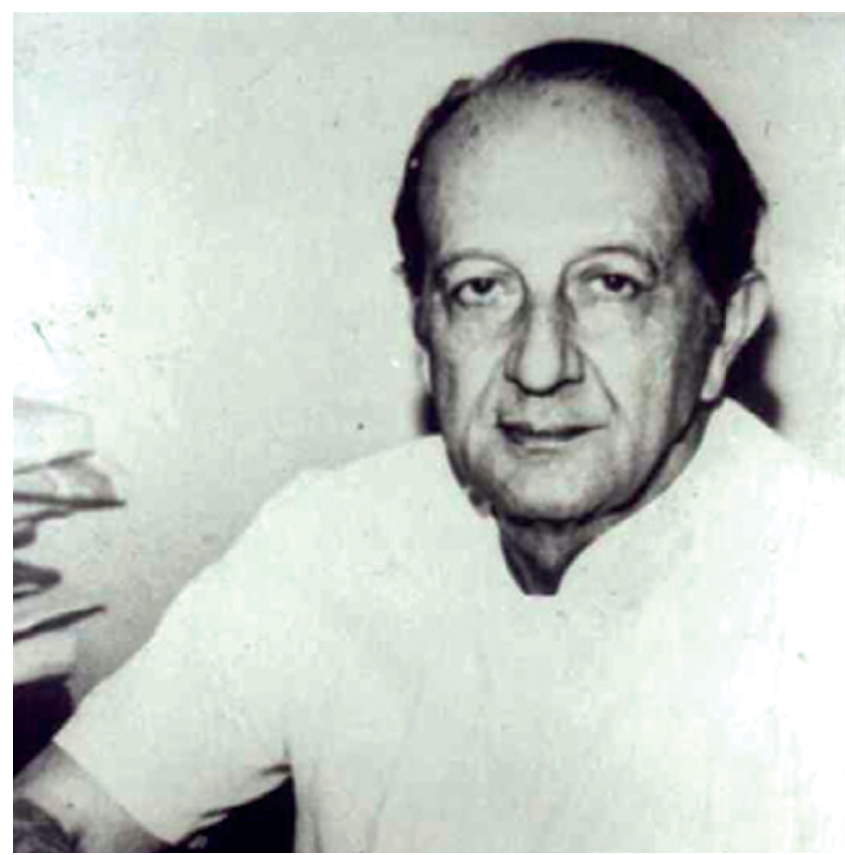

Figure 5. Antonio Rodrigues de Mello (1911-1988).

References

1. Philippon J, Léger JM. GBS:The early Years in Paris. In: Willison HG, Goodfellow JA. GBS 100. Narberth: GBS/CIDP Foundation International; 2016. p. 10-4.

2. Guillain G, Barré, JA, Strohl. Sur un syndrome de radiculonévrite avec hyper-albuminose du liquide céphalo-tachidien sans réaction cellulaire. Remarques sur les caractères cliniques et graphiques des réflexes tendineux. Bul Mém Soc Med Hôp Paris.1916:40:1462-70.

3. Ropper AH, Wijdicks EFM, Truax BT. Guillain-Barré syndrome. Philadelphia: FA Davis; 1991. History of Landry-Guillain-Barré syndrome; p. 3-17.

4. Landry 0. Note sur la paralisie ascendent. Gaz Hebd Méd Chir. 1859;6:472-74,486-88.

5. Pearce JMS. Octave Landry's ascending paralysis and the Landry-Guillain- Barré syndrome.J Neurol Neurosurg Psychiatry. 1997;62(5):495, 500.
6. Haymaker W. Octave Landry (1826-1865). In: Haymaker W, Schiller F. 2nd ed. Springfield: Charles C Thomas; 1970. p. 466-9.

7. Guillain G, Alajouanine TH, Pérrison J. Sur le syndromede radiculo-névrite aigue curable avec dissociation albumino-cytologique du liquide cephalo-rachidien (deux observations). Rev Neurol (Paris).1925;41:492-6.

8. Guillain G, Barré JA. Quelques remarques sur notre "Syndrome de radiculo-névrite avec hyperalbuminose du liquide céphalo-rachidien sans réaction cellulaire". Rev Neurol (Paris). 1936;65:573-82.

9. Alajouanine Th, Thurel H, Hornet TH, Boudin G. La poliradiculo-névrite géneralisée avec diplégie faciale et paralysie terminale des muscules respiratoires et avec dissociation albumino-cytologique: étude anatomique. Rev Neurol (Paris).1936;65:681-9.

10. Mello AR. Acerca das poly-radiculo-neurites generalizadas com dissociação albumino-cytologica. Brasil-Medico.1939;41:951-4. 